\title{
Toxicity and biosorption of chromium from aqueous solutions by the diatom Planothidium lanceolatum (Brébisson) Lange-Bertalot
}

\author{
Sbihi K. ${ }^{1}$, Cherifi O. ${ }^{1}$ and Bertrand $\mathrm{M}^{2}{ }^{2}$ \\ ${ }^{1}$ Laboratory of Bioprocess Engineering, Biology Department, Faculty of Sciences and \\ Techniques, Marrakech, PO Box 549, 40000 Marrakech, Morocco; \\ Tel number: 00212524433404, e-mail: agro_karim@yahoo.fr \\ ${ }^{2}$ INTECHMER - CNAM, BP324, F-50103 Cherbourg Cedex, France.
}

\begin{abstract}
The present study reports the ability of the diatom Planothidium lanceolatum (Brébisson) LangeBertalot $(P$. lanceolatum) to remove hexavalent chromium $[\mathrm{Cr}(\mathrm{VI})]$ from aqueous solutions in batch system under varying ranges of $\mathrm{pH}$, contact time and initial ion concentrations by the determination $\mathrm{Cr}(\mathrm{VI})$ toxic effects and biosorption by this species. The results show a significant growth of $P$. lanceolatum for $\mathrm{Cr}$ concentrations up to $10 \mathrm{mg} \mathrm{L}^{-1}$. The growth rate decreases as a function of increasing concentrations of $\mathrm{Cr}(\mathrm{VI})$. The cultures made with Tensift River water (Marrakech, Morocco) developed in the presence of $\mathrm{Cr}(\mathrm{VI})$ concentrations from 0 to $4 \mathrm{mg} \mathrm{L}^{-1}$. But the culture with tannery effluent water grew with concentrations from 0 to $0.152 \mathrm{mg} \mathrm{L}^{-1}$. The IC50 calculated is $8.7 \mathrm{mg} \mathrm{L}^{-1}$ for the artificial growth medium tested which is more than that calculated with river water $\left(3.85 \mathrm{mg} \mathrm{L}^{-1}\right)$ and tannery effluent water $\left(0.075 \mathrm{mg} \mathrm{L}^{-1}\right)$. The biosorption of $\mathrm{Cr}$ increases with the decrease of $\mathrm{pH}$. The biosorption capacity calculated from the Langmuir isotherm was $93.45 \mathrm{mg} \mathrm{Cr}(\mathrm{VI}) . \mathrm{g}$ diatoms ${ }^{-1}$ at an initial concentration of $0.4 \mathrm{~g}$ dried diatoms per liter with an initial $\mathrm{Cr}(\mathrm{VI})$ concentration of $20 \mathrm{mg} \mathrm{L}^{-1}$. The wide ecological valence of this diatom to pollution parameters and the seasonal pattern of its life cycle are the main factors that make the biomonitoring of $\mathrm{Cr}(\mathrm{VI})$ by this species feasible.
\end{abstract}

Keywords: Biosorption, Planothidium lanceolatum, hexavalent chromium, biomonitoring, wastewater.

\section{INTRODUCTION}

Metals ions are nowadays among the most important pollutants in surface and ground water. They are often discharged, by a number of industries, such as metal plating facilities, mining operations and tannery, which can lead to the contamination of freshwater and marine environment. Chromium is one of the contaminants, which exists in hexavalent $[\mathrm{Cr}(\mathrm{VI})]$ and trivalent $[\mathrm{Cr}(\mathrm{III})]$ forms. $\mathrm{Cr}(\mathrm{VI})$ is more toxic than $\mathrm{Cr}(\mathrm{III})$ one and requires more concern (Smith and Lec, 1972). It has been considered as one of the top 16 toxic pollutants and because of its carcinogenic and teratogenic potential effects on the human beings, $\mathrm{Cr}(\mathrm{VI})$ has become a serious health concern (Kowalski, 1994). It is therefore essential to remove it from wastewater before disposal. According to EPA (US Environmental Protection Agency), $\mathrm{Cr}$ concentrations range from 10 to 100 of $\mathrm{mg} \mathrm{L}^{-1}$. $\mathrm{Cr}$ (III) used in some tanneries and other manufacturing industries, is released and photo- oxidized in the more toxic $\mathrm{Cr}(\mathrm{VI})$ form. Both dissolved oxygen and the hydroxyl radical $\left({ }^{\circ} \mathrm{OH}\right)$ trigger the oxidation of $\mathrm{Cr}(\mathrm{III})$ to $\mathrm{Cr}(\mathrm{VI})$ via a multiple step pathway (Dai et al., 2010). This oxidation has been reported by many other authors (Bartlett and James, 1979; Stromberg et al., 1984).

Recently, heavy metal biosorption using biological material has emerged as a potential alternative instead of the existing conventional physicochemical methods (Aksu, 1998; Torres et al., 1998; Gupta et al., 2001). Among the biological material, algae have proved to be advantageous because they present several advantages, i.e. economic regeneration, metal recovery potentiality, lesser volume of chemical and / or biological sludge to be disposed off, high efficiency in dilute effluents and large surface area to volume ratio (Gupta and Rastogi, 2008). But their application to monitoring systems has not reached level of their significance (Whitton and Kelly, 1995). In addition, their utilization as low-cost adsorbents for 
the treatment of wastewater may make them of some value (Gupta and Ali, 2002; Ali and Gupta, 2007; Gupta et al., 2009). Moreover, diatoms are widely used to monitor river pollution because they are sensitive to water chemistry, especially ionic content, $\mathrm{pH}$, dissolved organic matter, and nutrients (Potapova and Charles, 2007).

In Marrakech (Morocco), an important pollution is generated by the tannery industry which discharges of metals into the Tensift River, and mainly chromium $(\approx 40$ tons/year) (Scandiaconsult International, 1999). Tannery wastewater flows directly into the environment without any treatment. So, $\mathrm{Cr}(\mathrm{VI})$ was detected in the Tensift River with high values exceeding International and National norms (Soudi and Xanthoulis, 2006), specially at low river discharge and high activity of tanneries where the maximum of total chromium and $\mathrm{Cr}(\mathrm{VI})$ recorded were 1.28 and $0.1 \mathrm{mg} \mathrm{L}^{-1}$, respectively. In Morocco, freshwater microalgae especially diatoms are only used for ecological purpose or for diatom indice applications to evaluate river water qualities. There are only few studies on metal toxicity and on diatom ability to remove metals from the environment (Zerhouni, 2003). But no work was done on diatoms in this field.

The objective of this study was to investigate the ability of the diatom Planothidium lanceolatum (Brébisson) Lange-Bertalot ( $P$. lanceolatum) to tolerate chromium by the determination of a share of the toxic effect of $\mathrm{Cr}(\mathrm{VI})$ under laboratory and simulated environmental conditions and to evaluate the effect of various parameters including contact time and $\mathrm{pH}$. Biosorption isotherm was applied to fit the experimental data. This species was chosen as biosorbent because it is one of the most abundant diatoms in the Tensift River and because of the relative lack of information about its biosorption ability. The main interest of this microalga lies in its ability to adapt easily to environmental factors and it is dominant during all the year (Sbihi, 2006).

\section{MATERIALS AND METHODS}

The places of procurement of chemicals and instruments used in the experimental study are the laboratory of Bioprocess Engineering at the Faculty of Sciences and Techniques and the Hydrobiology, Eco-toxicology and cleansing Laboratory at Semlalia Science Faculty.

Isolation and cultivation of the diatom: The microalga used was the benthic $P$. lanceolatum isolated from the Tensift River. $P$. lanceolatum was grown in sterilized modified WC medium at $\mathrm{pH}$ - 7 (Wright's Cryptophyta) (Guillards and Lorenzen, 1972). Algal cultures were maintained in Erlenmeyer flasks of 2 liters-capacity in order to provide sufficient quantity of biomass for experiments. Cultures were incubated in a culture room illuminated at $72 \mu \mathrm{E} \mathrm{m} \mathrm{m}^{-2} \mathrm{~s}^{-1}$, they were shacked under a light/dark cycle of $12 / 12$ for 10 days at $20^{\circ} \mathrm{C}$. Cultures were checked regularly microscopically. These cultures were deemed axenic.

Analysis of $\mathrm{Cr}(\mathrm{VI})$ and total $\mathrm{Cr}$ : The $\mathrm{Cr}(\mathrm{VI})$ concentrations of water and wastewater were determined by colorimetric technique $(540 \mathrm{~nm})$ with diphenylcarbazide (DPC) in acid solution as described in the standard method (Eaton et al., 2000). Total chromium amounts were determined by atomic absorption spectrophotometry (AAS) (UNICAM 929).

Growth rate inhibition bioassays: A batch method was used for growth-rate-inhibition bioassays using 250-mL borosilicate glass Erlenmeyer flasks, coated with Coatasil silanising solution to prevent adsorption of chromium to the glass. Test flasks were soaked in $10 \%(\mathrm{v} / \mathrm{v})$ nitric acid overnight and rinsed thoroughly with distilled water. A stock solution $\left(1000 \mathrm{mg} \mathrm{L}^{-1}\right)$ of $\mathrm{Cr}$ (VI) was prepared from solid potassium dichromate $\mathrm{K}_{2} \mathrm{Cr}_{2} \mathrm{O}_{7}$, generating $\mathrm{Cr}(\mathrm{VI})$. The stock solution was then appropriately diluted in the WC medium. The cells used in the experiments were transferred at an exponential phase to the WC medium.

Three culture media were tested. The WC culture medium, the tannery effluent water (collected at point N 31 $38^{\circ}$ ' 4.64" W $7^{\circ} 58^{\prime} 44.76$ ") and in Tensift River water (collected at point $\mathrm{N} 31^{\circ} 41^{\prime} 50.61^{\prime \prime} \mathrm{W} 8^{\circ} 3^{\prime}$ 48.07").

Toxicity of $\mathrm{Cr}$ (VI) in the WC medium: the tested concentrations ranged from 0 to $20 \mathrm{mg} \mathrm{L}^{-1}$. The higher concentrations were used to better simulate concentrations rejected in the tannery effluent $(38 \mathrm{mg}$ $\left.\mathrm{L}^{-1}\right)$. Preliminary tests with concentrations higher than 20 don't allow $P$. lanceolatum development.

Toxicity of Tensift River: the water samples taken from the Tensift River contained approximatively 0.1 $\mathrm{mg} \mathrm{L}^{-1}$ of $\mathrm{Cr}(\mathrm{VI})$. And for the control [without $\mathrm{Cr}(\mathrm{VI})$ ], we have used river water upstream of tannery effluents. For testing the $\mathrm{Cr}(\mathrm{VI})$ toxicity on $P$. lanceolatum toxicity, $\mathrm{Cr}(\mathrm{VI})$ was inoculated at different concentrations ranging from 0.05 to $10 \mathrm{mg} \mathrm{L}^{-}$ ${ }^{1}$ to test the ability of the diatom in removing high concentrations, if there are, in river water. 
Toxicity of tannery effluent: $P$. lanceolatum was exposed to tannery effluent water at different $\mathrm{Cr}(\mathrm{VI})$ concentrations ranging from 0.038 to $0.76 \mathrm{mg} \mathrm{L}^{-1}$. The water of the Tensift River [without $\mathrm{Cr}(\mathrm{VI})$ ] was employed as dilution water for preparing the simulated effluents.

For the three toxicity tests, each flask was inoculated with $10^{4}$ cells $\mathrm{mL}^{-1}$ of a prewashed $P$. lanceolatum suspension according to OECD recommendation (1984). This low cell density was used to better simulate algal concentrations in the river. Flasks were incubated under the same conditions as mentioned above. Algal cell density was determined daily using a hemocytometer Malassez cell. Cell growth was considered as a parameter to monitor the toxic effect of $\mathrm{Cr}(\mathrm{VI})$ on $P$. lanceolatum. Sub-samples $(5 \mathrm{~mL})$ were taken from each flask at the beginning of each toxicity and biosorption test, prior for the determination of dissolved $\mathrm{Cr}(\mathrm{VI})$. In order to determine the $\mathrm{Cr}(\mathrm{VI})$ biosorbed, $30 \mathrm{ml}$ of culture were filtered on a $0.45 \mu \mathrm{m}$ Millipore filter and the $\mathrm{Cr}(\mathrm{VI})$ in filtrate was determined.

Biosorption studies: Biosorption experiments were carried out in batch in $250 \mathrm{ml}$ Erlenmeyer flasks to determine the best conditions ( $\mathrm{pH}$ and contact time) at which the maximum $\mathrm{Cr}(\mathrm{VI})$ biosorption was observed. These flasks were kept on a rotatory shaker at $150 \mathrm{rpm}$. After they were shaked for desired time periods, the cultures were filtered on a $0.45 \mu \mathrm{m}$ Millipore filter and then the filtrate was analyzed for $\mathrm{Cr}(\mathrm{VI})$ concentration.

The effect of $\mathrm{pH}$ on $\mathrm{Cr}(\mathrm{VI})$ biosorption by $P$. lanceolatum was determined for $\mathrm{pH}$ values from 1 to 7 because the lower $\mathrm{pH}$ measured in the tannery effluents was 2.5 and the main $\mathrm{pH}$ value in the Tensift River was 6.9. The $\mathrm{pH}$ was adjusted using $0.1 \mathrm{~N} \mathrm{HCl} / \mathrm{NaOH}$. Dried $P$. lanceolatum $(0.4 \mathrm{~g})$ was added to $100 \mathrm{ml}$ of culture medium with $10 \mathrm{mg}$ of $\mathrm{Cr}(\mathrm{VI}) \mathrm{L}^{-1}$, in 250-ml Erlenmeyer flasks. The kinetic study for biosorption of $\mathrm{Cr}$ (VI) were conducted at varying initial $\mathrm{Cr}(\mathrm{VI})$ concentrations in the range of 1$20 \mathrm{mg} \mathrm{L}^{-1}$. Samples of $5 \mathrm{ml}$ were collected at definite time intervals from 15 to 1440 min for the $\operatorname{Cr}(\mathrm{VI})$ concentration determination.

The data obtained in batch biosorption studies was used to calculate the equilibrium metal biosorption capacity. The Langmuir biosorption model was adopted for the estimation of maximum $\mathrm{Cr}(\mathrm{VI})$ uptake $\left(q_{\max }\right)$ where they could not be reached in the experiment (Langmuir, 1916)

$$
q=\frac{q_{\max } b C_{e q}}{1+b C_{e q}}
$$

where $q$ is the amount in milligrams of metal biosorbed per gram of biosorbent material; $\mathrm{C}_{\mathrm{eq}}$ is the metal residual concentration in solution; $\mathrm{q}_{\max }$ is the maximum specific uptake and $b$ is the energy of biosorption.

Data handling and statistical analysis: All the experiments were carried out in triplicate and the mean values with standard deviation are presented.

The IC50, i.e. the inhibitory concentration to reduce the growth rate by $50 \%$, was calculated during exponential growth phase, using linear interpolation method for sub-lethal toxicity using statistical software (ICp Ver.2.0) (Norberg-King, 1993). The data were tested for normality and homogeneity of variance. The confidence interval is $95 \%$ for all parameters tested. Tests for significance between treatments were determined using a one-way analysis of variance (ANOVA), and the Duncan test $(p<0.05)$ was used for detection of differences between groups. All analyses were carried out using the program SPSS 17.0 for Windows.

\section{RESULTS}

The quantitative determination of $\mathrm{Cr}(\mathrm{VI})$ used concentrations shows that they have been maintained close to the desired nominal concentration. Thus, the analysis of the results has been based on nominal concentrations. Also, among replicates, we notice that there is no significant variability $(P<0.05)$.

The choice of $\mathrm{Cr}(\mathrm{VI})$ concentrations in this study was done according to the total chromium $\left(1.2 \pm 0.12 \mathrm{~g} \mathrm{~L}^{-1}\right.$ ) and $\mathrm{Cr}(\mathrm{VI})\left(38 \pm 1.32 \mathrm{mg} \mathrm{L}^{-1}\right)$ concentrations found in tannery effluent water of Marrakech city.

Toxicity test: Figure 1 illustrates the growth of $P$. lanceolatum cells exposed to different $\mathrm{Cr}(\mathrm{VI})$ concentrations. The maximum cell density reached in control cultures was $25.4 \times 10^{5}$ cells $\mathrm{mL}^{-1}$. Duncan statistical analysis of this experiment shows that there is a significant difference between maximum cell densities achieved in all cultures from that obtained in control cultures $(\mathrm{P}<0.05)$. But $\mathrm{Cr}(\mathrm{VI})$ concentrations of 2,4 and $10 \mathrm{mg} \mathrm{L}^{-1}$ triggered a same decrease in growth when compared with the other tested concentrations $(P<0.05)$ and suggests that this diatom has the same tolerance to these concentrations. The maximum cell density obtained in these cultures was nearly 2 times lower than those 
reached in control cultures. But the higher $\mathrm{Cr}(\mathrm{VI})$ concentration $\left(20 \mathrm{mg} \mathrm{L}^{-1}\right)$ affects more seriously the algal growth. The maximum cell density at the $10^{\text {th }}$ day of experiment did not exceed $3 \times 10^{5}$ cells $\mathrm{mL}^{-1}$.

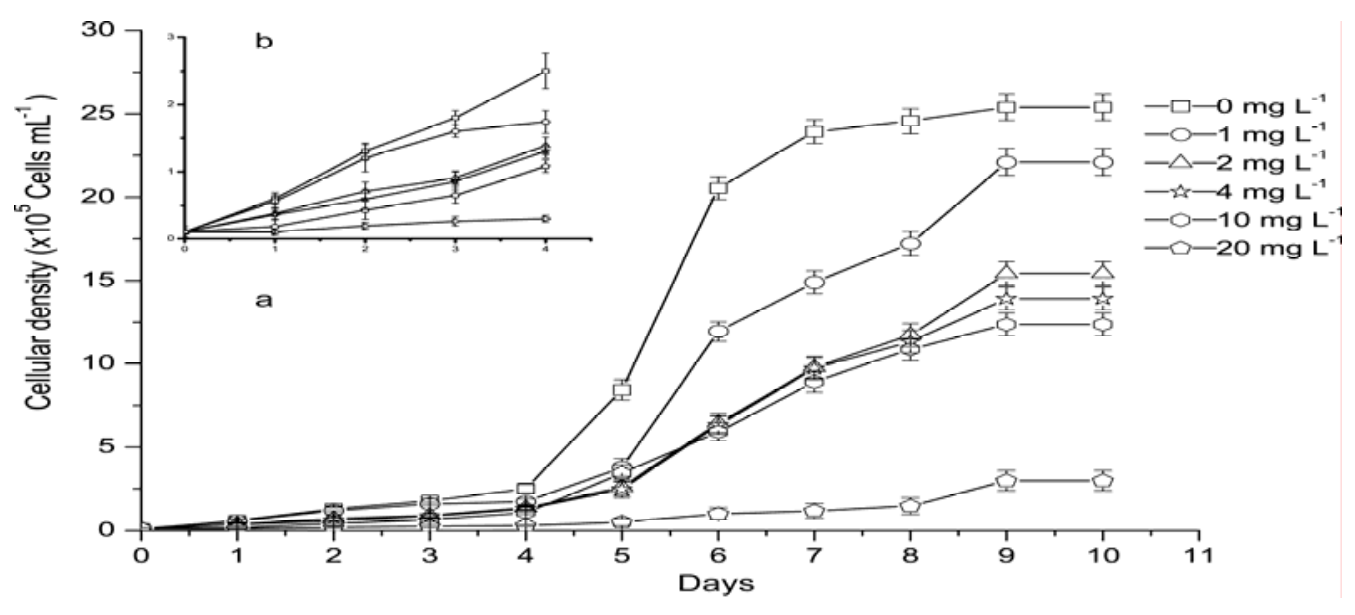

Fig. 1 Growth curves of $P$. lanceolatum cells exposed to different $\mathrm{Cr}(\mathrm{VI})$ concentrations during the long term exposure (a). The insert shows the growth curves during the first 4 days (b) (mean values $\pm S D ; n=3$ ).

Growth rates decreased as $\mathrm{Cr}(\mathrm{VI})$ concentration in the medium increased $(r=-0.96)$ and maximum growth rates were obtained in control cultures and in culture with $1 \mathrm{mg} \mathrm{L}^{-1}$ of $\mathrm{Cr}(\mathrm{VI})\left(0.9 \mathrm{day}^{-1}\right)$. The IC50 value calculated during the period of exposure to $\mathrm{Cr}(\mathrm{VI})$ was $8.7 \mathrm{mg} \mathrm{L}^{-1}$.

In order to support these results, and to test the ability of this diatom to remove $\mathrm{Cr}(\mathrm{VI})$ directly from Tensift River where the alga thrives, and from tannery effluents, analogous tests using these waters instead of culture media were performed. Figure 2 and 3 illustrate the growth curves of $P$. lanceolatum cells exposed to different $\mathrm{Cr}(\mathrm{VI})$ concentrations of Tensift River and tannery effluents waters, respectively, during the period of study. Results show that this diatom tolerates concentrations of $\mathrm{Cr}(\mathrm{VI})$ until $4 \mathrm{mg} \mathrm{L}^{-1}$ and $0.152 \mathrm{mg} \mathrm{L}^{-1}$ for Tensift River and tannery effluents waters, respectively, which are less than that found with culture media. The IC50 values calculated during the period of exposure are just 3.85 $\mathrm{mg} \mathrm{L}^{-1}$ and $0.075 \mathrm{mg} \mathrm{L}^{-1}$, respectively, for river water and tannery wastewater.

\section{Biosorption of $\mathrm{Cr}(\mathrm{VI})$}

Effect of contact time: $P$. lanceolatum cells are able to accumulate $\mathrm{Cr}(\mathrm{VI})$. Figures 4 shows the effect of contact time on the extent of biosorption of $\mathrm{Cr}(\mathrm{VI})$ by this microalga for different concentrations of $\mathrm{Cr}(\mathrm{VI})$. The results are given for the first 2 hours. It has been observed that the biosorption efficiency is maximum within the first $30 \mathrm{~min}$. It reached $91 \%$ and $98 \%$ for the lower $\mathrm{Cr}(\mathrm{VI})$ concentrations $\left(1\right.$ and $\left.2 \mathrm{mg} \mathrm{L}^{-1}\right)$. This increase was only $70 \%$ for higher concentrations (10 and $20 \mathrm{mg} \mathrm{L}^{-1}$ ). 


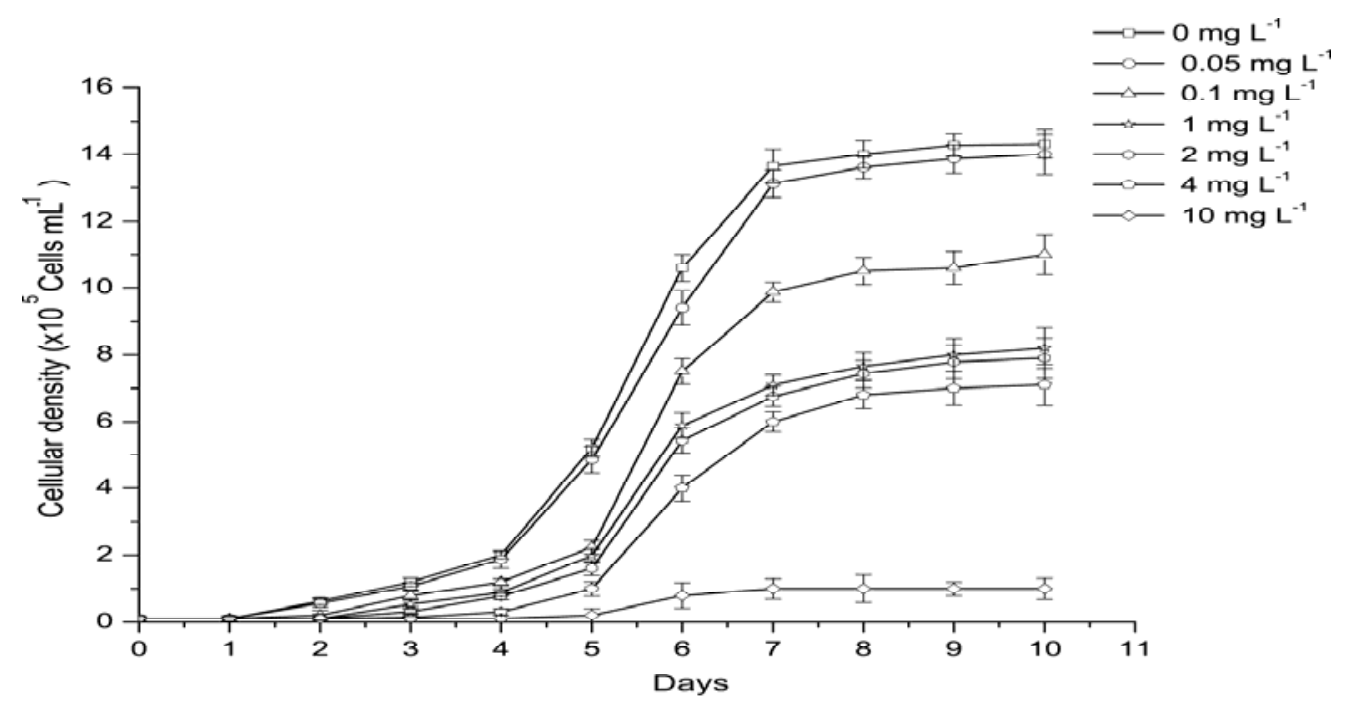

Fig. 2 Growth curves of P. lanceolatum cells exposed to different $\mathrm{Cr}(\mathrm{VI})$ concentrations of Tensift River water during the long term exposure (mean values $\pm S D ; n=3$ )

Figure 5 shows the effect on contact time on the extent of biosorption of $\mathrm{Cr}(\mathrm{VI})$ by the diatom for the long term exposure during the toxicity test. Results show that the biosorption of $\mathrm{Cr}(\mathrm{VI})$ by the diatom was maintained during the 10 days of study. In culture with $20 \mathrm{mg} \mathrm{L}^{-1}$ of $\mathrm{Cr}(\mathrm{VI})$, although the algal density and the growth were lower (Figure 1), $\mathrm{Cr}(\mathrm{VI})$ removal is almost complete (98\%). For all $\mathrm{Cr}(\mathrm{VI})$ concentrations, the difference in biosorption between day 2 and day 10 is not significant (between 8 and $19 \%$ of $\mathrm{Cr}(\mathrm{VI})$ biosorbed).

To determine the effect of Tensift River water on the diatom biosorption, the amount of $\mathrm{Cr}(\mathrm{VI})$ at days 1, 2, 3 and 10 was measured. Results show that $\mathrm{Cr}(\mathrm{VI})$ removal increased with the increase of $\mathrm{Cr}(\mathrm{VI})$ concentrations. The minimum and the maximum $\mathrm{Cr}(\mathrm{VI})$ removed were $39 \%$ and $61 \%$, respectively (Figure 6). In comparison with WC medium test, the amount of $\mathrm{Cr}(\mathrm{VI})$ removal decreased from $73 \%$ to $39 \%$ and from $98 \%$ to $61 \%$ for the lower and the higher $\mathrm{Cr}(\mathrm{VI})$ tested concentrations, respectively.
Effect of $\mathbf{p H}$ : Earlier studies have indicated that the $\mathrm{pH}$ of a medium is an important parameter affecting biosorption of metals (Franklin et al., 2000; Gupta and Rastogi, 2008). Figure 7 illustrates the biosorption of $\mathrm{Cr}(\mathrm{VI})$ as a function of $\mathrm{pH}$. From this figure, it is clear that the percentage of $\mathrm{Cr}(\mathrm{VI})$ biosorption increases with the decrease of $\mathrm{pH}: 50 \%$ biosorption was measured at $\mathrm{pH} 7$ whereas $85 \%$ was reached at the extreme $\mathrm{pH}$ of 1 .

Langmuir adsorption isotherm : The found linear plot of $\mathrm{C}_{\text {eq }} / \mathrm{q}$ vs $\mathrm{C}_{\text {eq }}$ shows that biosorption follows the Langmuir biosorption model. The correlation coefficient was 0.995 . The values for $q_{\max }$ and $b$ were determined from the slope and intercept of the plot and were found to be $93.45 \mathrm{mg} \mathrm{Cr}(\mathrm{VI}) . \mathrm{g}^{-1 i a t o m s}{ }^{-1}$ and $0.13 \mathrm{~L} \mathrm{mg}^{-1}$, respectively.

\section{DISCUSSION}

During these last decades, the effects of increased levels of metals on epiphytic or phytoplanctonic algal communities have been extensively studied under laboratory and natural conditions (Jennett et al., 1980; Levkov and Krstic, 2002; Morin et al., 2008; Gupta et al., 2008). Generally in natural communities, investigations are performed on several days of exposure that simulates natural situations (Genter, 1996). This is the reason why we study a long term exposure to $\mathrm{Cr}(\mathrm{VI})$ of $P$. lanceolatum to test the ability of this diatom to remove $\mathrm{Cr}(\mathrm{VI})$ under laboratory conditions in a first step. Then, we substituted the culture medium with tannery effluent and river waters 
to have a simulation of the biomonitoring of this diatom.

According to Figure 1, as the $\mathrm{Cr}(\mathrm{VI})$ concentration increased in the medium, total $P$. lanceolatum growth decreased. Despite the use of a low initial cell density, the culture grew in different conditions during the long-term exposure time, except in the highest concentration $\left(20 \mathrm{mg} \mathrm{L}^{-1}\right)$. The difference between the cellular density at 2,4 and $10 \mathrm{mg} \mathrm{L}^{-1}$ ranges within $20 \%$ which is not significant according to Duncan statistical analysis. It suggests that this species has a large tolerance to $\mathrm{Cr}(\mathrm{VI})$ concentrations up to $10 \mathrm{mg} \mathrm{L}^{-1}$. For $\mathrm{Cr}(\mathrm{VI})$ concentration of $20 \mathrm{mg} \mathrm{L}^{-1}$, diatoms seem to recover from day 9 that could mean that $\mathrm{Cr}(\mathrm{VI})$ may have an algistatic rather than an algicide effect. Previous studies showed that the $\mathrm{Cr}(\mathrm{VI})$ concentrations that affect growth in microalgae are largely variable and depend on different test conditions such as cell densities and test media used (Dönmez et al., 1999; Stauber and Davies, 2000; Wang and Dei, 2001 ).

The same test was done with tannery effluent and river waters (Figure 2 and 3 ) and it demonstrates the influence of the environmental conditions on algal growth. The cultures with Tensift River water grew in $\mathrm{Cr}(\mathrm{VI})$ concentrations lower than $10 \mathrm{mg} \mathrm{L}^{-1}$ (Figure 2). The culture with tannery effluent water grew with concentrations not higher than $0.152 \mathrm{mg} \mathrm{L}^{-1}$ (Figure 3 ). Tensift river water and tannery effluent are surely complex matrices containing a large number of contaminants which can be responsible for part of the observed toxicity and for the higher sensitivity of $P$. lanceolatum to $\mathrm{Cr}(\mathrm{VI})$ in this medium. Indeed, the $\mathrm{BOD}_{5}(45 \pm 0.45)$ and the COD $(2500 \pm 13.08)$ of the tannery effluent are sharply higher (Tiglyene et al., 2005). Thus, the suitability of a given species for $\mathrm{Cr}(\mathrm{VI})$ remediation must be verified in the actual matrix to treat. Many authors had reported that organisms show an integrating response to their environment, as well as to fluctuations in water quality (Jennet et al., 1980; Levkov and Krstic, 2002). This is the reason why the growth of $P$. lanceolatum was affected. But in general, this diatom tolerates $\mathrm{Cr}(\mathrm{VI})$ concentrations up to $4 \mathrm{mg} \mathrm{L}^{-1}$ in Tensift river water which is much higher in comparison with other works (Aksu et al., 1996; Dönmez et al., 1998). In fact, Hervy (1949) had reported that 7 species of algae could tolerate no more than 6.4 (chlorophyceae) and 0.32 (diatoms) $\mathrm{mg} \mathrm{L}^{-1}$ of chromium. Also, $P$. lanceolatum is considered to be an eurytopic species, able to tolerate a wide range of environmental changes, with a wide cosmopolitan distribution (Kawecka et al., 1998; Kawecka and Olech, 2004; Noga and Olech, 2004).

The IC50 value calculated for this microalga during the 10 days of the study was $8.7 \mathrm{mg} \mathrm{L}^{-1}$ and it is much higher in comparison with other species. For instance, Pena-Castro (2002) studied the IC50-72h of chromium on the growth of the green microalga Scenedesmus incrassatulus in a batch culture, which was $2.09 \mathrm{mg} \mathrm{L}^{-1}$. Similarly with respect to the Chlorophyceae, Chlorella vulgaris tolerates concentrations not exceeding $1 \mathrm{mg} \mathrm{L}^{-1}$ (Deng et al., 2006). P. lanceolatum appears again, more tolerant to this metal.

As shown in Figure 4, the $\mathrm{Cr}(\mathrm{VI})$ removal by $P$. lanceolatum differed between the various concentrations of $\mathrm{Cr}(\mathrm{VI})$ in the medium. However, the maximum $\mathrm{Cr}(\mathrm{VI})$ sorption rate was observed during the first $30 \mathrm{~min}$. According to some authors (MorenoGarrido et al., 1997; Moreno-Garrido, 2000) some microalgal species such as Nannochloropsis gaditana are able to remove $100 \%$ of metals in less than 2 days. Also, Torres et al. (1998) have found that within the first few minutes of exposure to cadmium, most of it was removed thanks to biosorption by the diatom Phaeodactylum tricornutum which metabolism can be disturbed some minutes later (Bertrand et al., 2001). In contrast, the $\mathrm{Cr}(\mathrm{VI})$ removed during the toxicity test is maintained until the $10^{\text {th }}$ day with a slow uptake (Figure 5). It has been reported that the biosorption of heavy metal ions by microorganisms has often been observed to occur in two phases; (i) the initial phase is very rapid occurring immediately after exposure to metal and probably passive and due to surface adsorption on the cell wall components (ii) the second phase is extended and slow down with duration of more than one month due to membrane transport of metal ions to the cytoplasm of the cells (Pickering and Puia, 1969; Vymazal, 1990; Genter, 1996; Aksu et al., 1996; Gupta, 2008). It suggests that $P$. lanceolatum removes $\mathrm{Cr}(\mathrm{VI})$ by adsorption and absorption. For the high $\mathrm{Cr}(\mathrm{VI})$ concentrations where the percentage of dead cells exceeded $50 \%$, better performance of biosorption was noted in comparison with living ones (low $\mathrm{Cr}(\mathrm{VI})$ concentrations). Actually, such a difference has already been observed with algae (Volesky, 1994). Dead cells do not require a nutrient supply (Patricia and Stone, 2002). Therefore, the use of dead algal cells is more advantageous for water treatment as they do not cope with toxic metals (Wilde and Benemann, 1993; Aksu, 1998). 


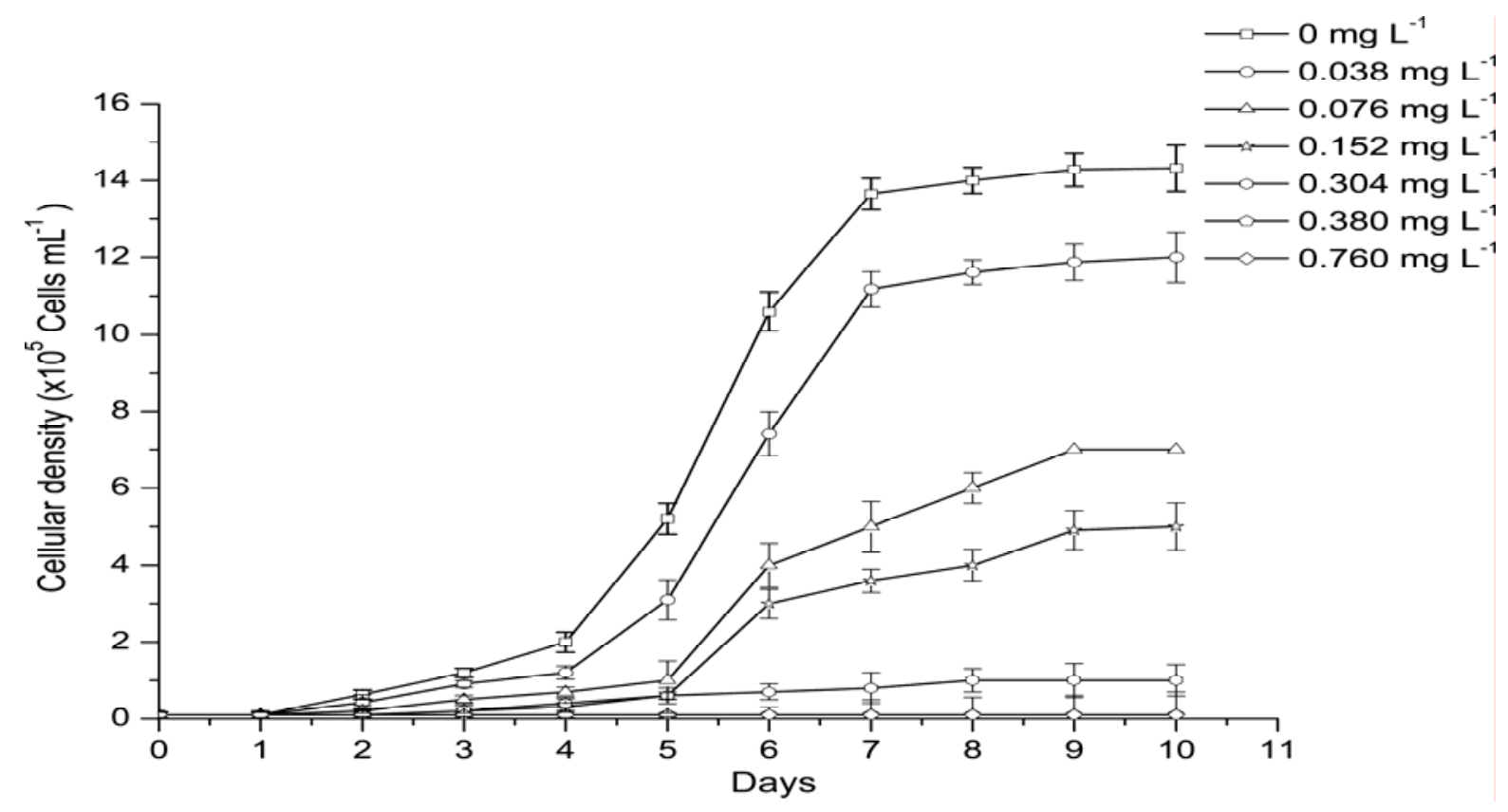

Fig. 3 Growth curves of $P$. lanceolatum cells exposed to different $\mathrm{Cr}(\mathrm{VI})$ concentrations of tannery effluent water during the long term exposure (mean values $\pm S D ; n=3$ ).

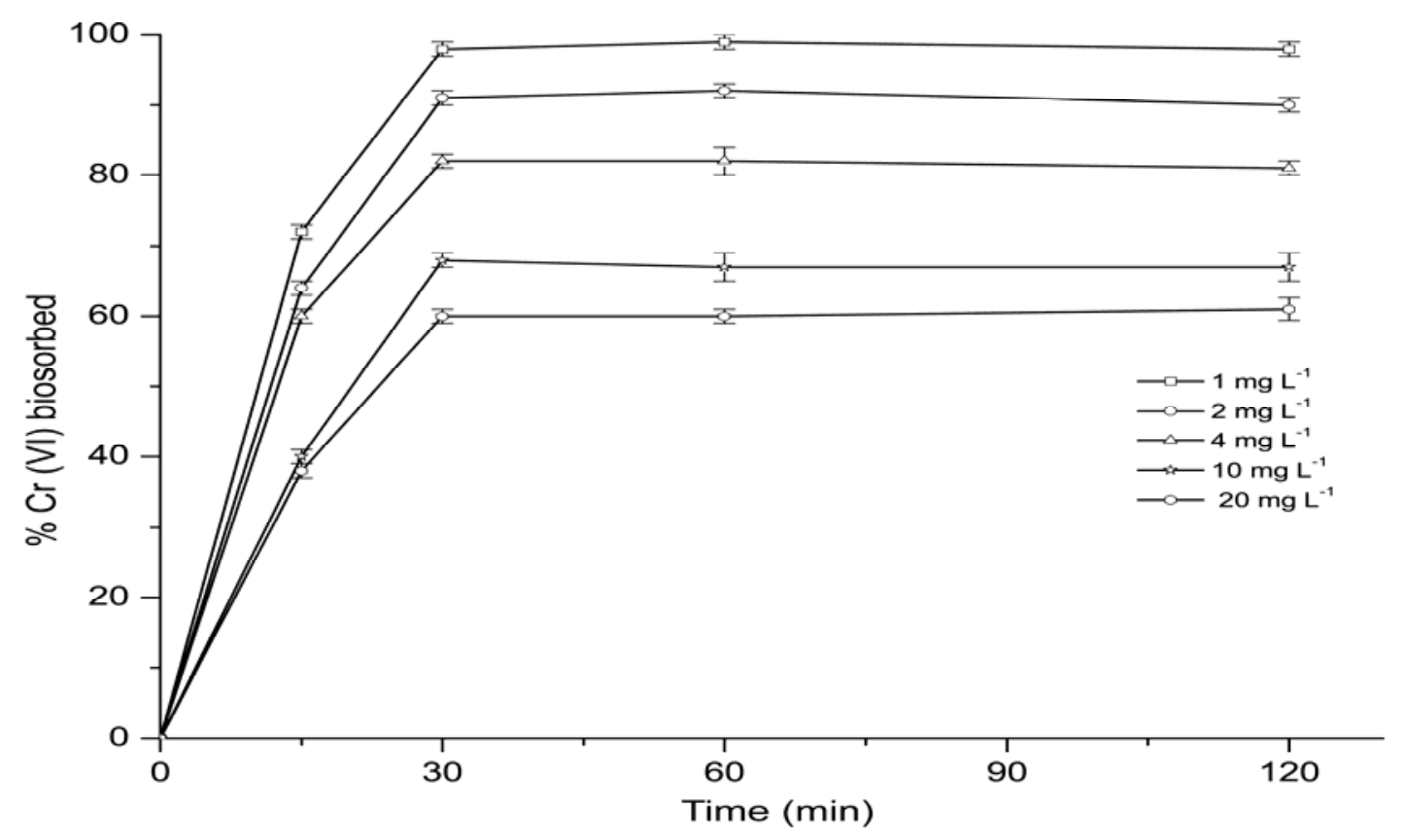

Fig. 4 Effect of contact time on the biosorption of $\mathrm{Cr}(\mathrm{VI})$ by $P$. lanceolatum at different concentrations in the artificial WC medium (Temperature: $20^{\circ} \mathrm{C}$, amount of diatoms: $0.4 \mathrm{~g} \mathrm{~L}^{-1}, \mathrm{pH} \mathrm{1.0,} \mathrm{(mean} \mathrm{values} \pm \mathrm{SD}$; $\mathrm{n}=3$ ). 


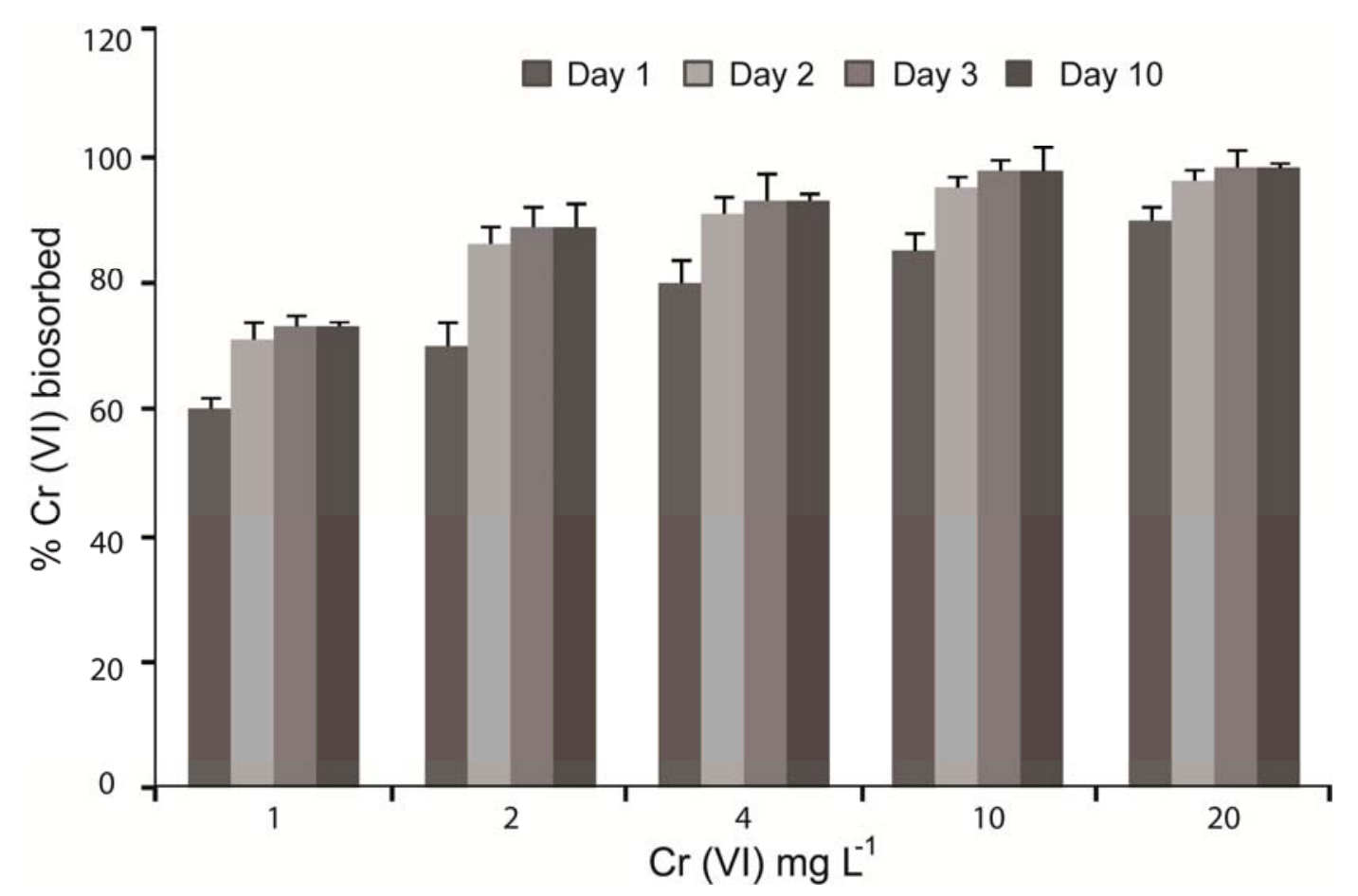

Fig. 5 Percentage of $\mathrm{Cr}(\mathrm{VI})$ biosorption by $P$. lanceolatum cells after $1,2,3$ and 10 days of exposure to different $\mathrm{Cr}(\mathrm{VI})$ concentrations in the artificial WC medium (mean values $\pm \mathrm{SD} ; \mathrm{n}=3$ ).

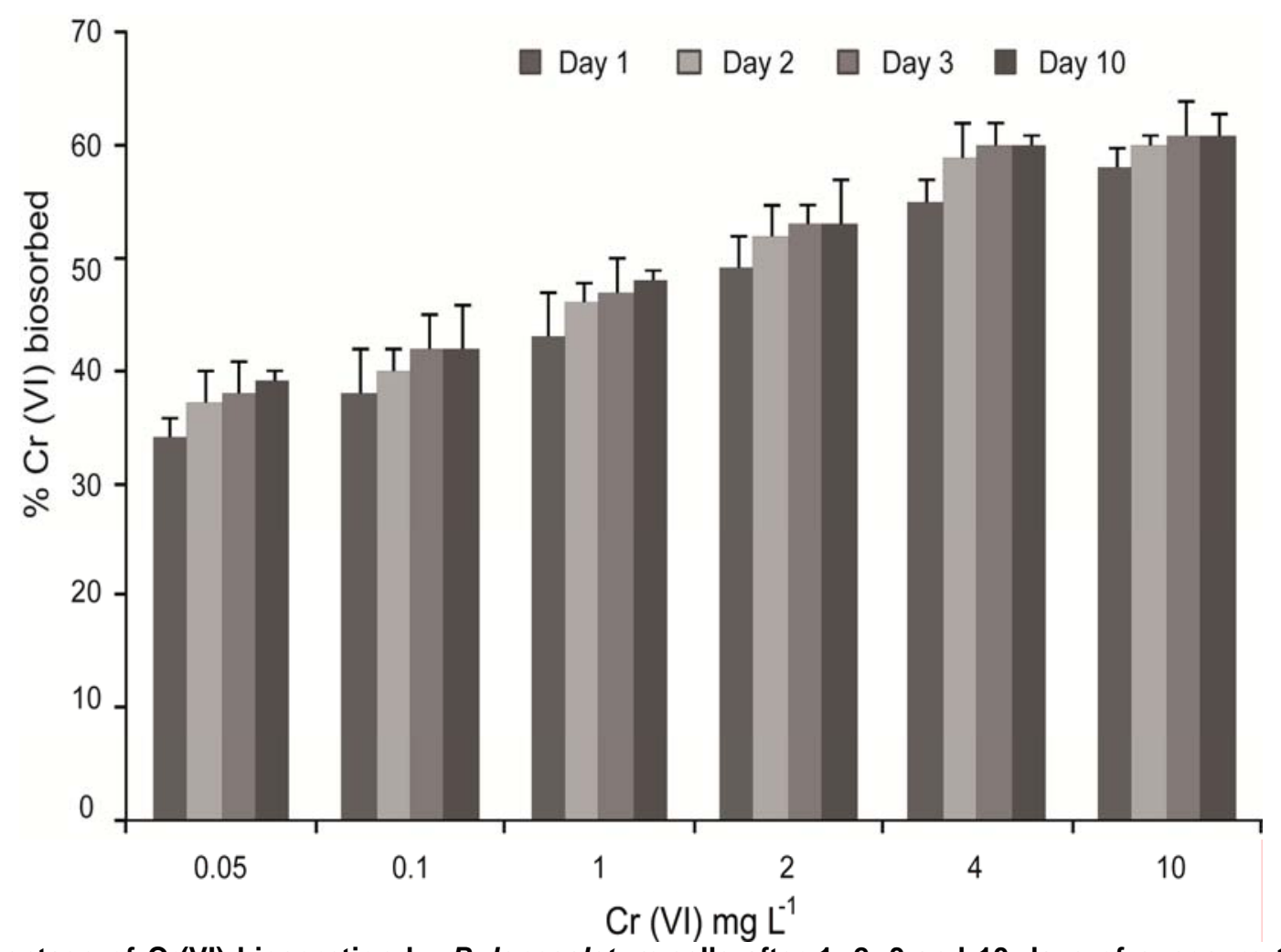

Fig. 6 Percentage of $\mathrm{Cr}(\mathrm{VI})$ biosorption by $P$. lanceolatum cells after 1, 2, 3 and 10 days of exposure to different $\mathrm{Cr}(\mathrm{VI})$ concentrations in Tensift River water (mean values $\pm \mathrm{SD} ; \mathrm{n}=3$ ). 
The results of the effect of $\mathrm{pH}$ (Figure 7) show the $\mathrm{pH}$-dependence biosorption and the suitability of biosorbent for treatment of acid water like tannery effluent water where the $\mathrm{pH}$ is acid (2.5). Many authors found that the maximum biosorption for algal species is at very acid pH values (Gupta et al., 2001, 2009; Han et al., 2007, Yang and Chen, 2008).

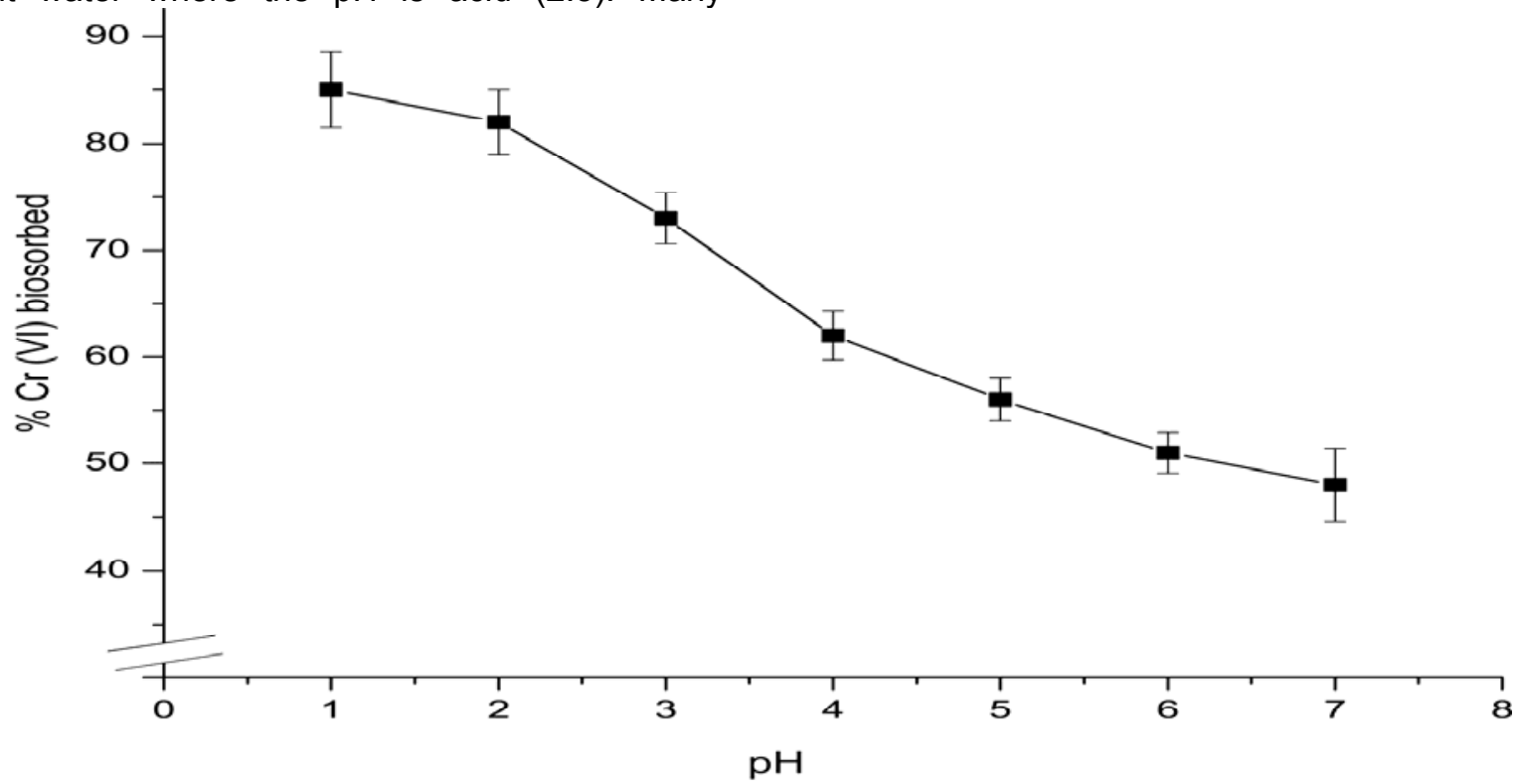

Fig. 7 Effect of the pH of artificial WC medium on the biosorption of $\mathrm{Cr}(\mathrm{VI})$ by $P$. lanceolatum. (Temperature: $20^{\circ} \mathrm{C}$, amount of diatoms: $0.4 \mathrm{~g} \mathrm{~L}^{-1}, \mathrm{Cr}(\mathrm{VI})$ concentration: $10 \mathrm{mg} \mathrm{L}^{-1}$, contact time: $30 \mathrm{~min}$ (mean values $\pm \mathrm{SD}$; $\mathrm{n}=3$ ).

The linearized biosorption isotherm of $\mathrm{Cr}(\mathrm{VI})$ ions obtained shows a very high regression correlation coefficient $(>0.99)$. This value strongly supports the fact that the $\mathrm{Cr}(\mathrm{VI})$ algal biosorption data closely follows the Langmuir model of sorption model and is very suitable for describing the equilibrium isotherm of $\mathrm{Cr}(\mathrm{VI})$ by the algal cells in the studied concentration range. The value of $\mathrm{q}_{\max }$ appears to be significantly higher for the $\mathrm{Cr}(\mathrm{VI})$. A large value of "b" also implied strong bonding to $\mathrm{Cr}(\mathrm{VI})$ to the $P$. lanceolatum cells. Table 1 shows a comparison between the results of this work and others found in the literature. The value of $\mathrm{Cr}(\mathrm{VI})$ specific uptake found in this work was generally higher than those reported elsewhere. But it is lower than that reported for the cyanobacteria Synechocystis sp.

Table 1 A comparison of the Langmuir biosorption constants obtained from the Langmuir biosorption isotherms for $\mathrm{Cr}(\mathrm{VI})$ ions and algal species.

\begin{tabular}{|l|l|l|l|l|}
\hline Biosorbant & $\mathbf{q}_{\max }\left(\mathbf{m g ~ g}^{-\mathbf{1}}\right)$ & $\mathbf{b} \mathbf{( \mathbf { ~ } \mathbf { ~ m g } ^ { - \mathbf { 1 } } )}$ & $\mathbf{R}^{\mathbf{2}}$ & Reference \\
\hline Chlorella vulgaris & 79.3 & 0.003 & 0.937 & Dönmez et al. (1999) \\
\hline Scenedesmus obliquus & 58.8 & 0.005 & 0.868 & Dönmez et al. (1999) \\
\hline Chlamydomonas reinhardtii & 24.9 & n.a & 0.998 & Arica et al. (2005) \\
\hline Synechocystis sp. & 153.6 & 0.002 & 0.921 & Dönmez et al. (1999) \\
\hline Planothidium lanceolatum & 93.45 & 0.13 & 0.995 & This work \\
\hline
\end{tabular}

n.a $a^{1}$ not available

Thus, $P$. lanceolatum is a diatom very tolerant to $\mathrm{Cr}(\mathrm{VI})$. Its growth is only inhibited by more than $4 \mathrm{mg}$ $\mathrm{L}^{-1}$ in Tensift River. In addition, the wider ecological valence of this diatom to pollution parameters and the seasonal pattern of the life cycle are the main factors that make the biomonitoring of $\mathrm{Cr}(\mathrm{VI})$ based on this species feasible. This performance encourages us to test the capacity of other toxic metal phytoextraction by this alga and by other eurytopic diatoms in Tensift River because the diatoms are present in all river systems and can easily be introduced onto natural stones (Levkov and Krstic, 2002). Other authors have 
reported that periphyton, especially diatoms, have been preferred for river biomonitoring (Biggs, 1989; Gomà et al., 2005)

\section{CONCLUSION}

This study indicates that the diatom $P$. lanceolatum which is widely available can be used as biosorbent material for removal of $\mathrm{Cr}(\mathrm{VI})$ from tannery effluents and from Tensift River waters. The adsorption process is fast enough, as a high removal rate takes place within half an hour of contact time. In comparison with other studied algae, $P$. lanceolatum is more resistant to high levels of $\mathrm{Cr}(\mathrm{VI})$ and can accumulate high amounts of this element. The IC50 calculated is $8.7 \mathrm{mg} \mathrm{L}^{-1}$ under laboratory conditions; it is higher than that calculated with tannery effluent and river waters which is an integrating response to its environment. Thus, the suitability of a given species for $\mathrm{Cr}(\mathrm{VI})$ remediation must be verified in the actual matrix to treat. The maximum $\mathrm{Cr}(\mathrm{VI})$ biosorption capacity for $P$. lanceolatum was found to be $93.45 \mathrm{mg} \mathrm{Cr}(\mathrm{VI}) . \mathrm{g}$ diatoms ${ }^{-1}$ at an initial concentration of $0.4 \mathrm{~g}$ dried diatoms per liter with initial $\mathrm{Cr}(\mathrm{VI})$ concentration of $20 \mathrm{mg} \mathrm{L}^{-1}$. The equilibrium data fitted well in the Langmuir isotherm. Biosorption experiments showed that the microalgae $P$. lanceolatum possesses a very high maximum biosorption capacity that depends on biomass growth conditions. Further studies are necessary to ascertain results with other initial algal densities and higher efficiencies in the adsorption process of the microalgae. Later on, practical applications of such techniques at larger scales would be useful for bioremediation of heavy metal polluted wastewaters since there is a lack of industrial wastewater treatment. Therefore, $P$. lanceolatum - and possibly other microalgae - may have the potential to be used as an ecofriendly and economic biosorbent cheap material for the removal of toxic metals in polluted waters.

\section{ACKNOWLEDGMENTS}

The authors are in debt to the tannery workers for their help in taking samples and for some interesting informations given. Also, the authors thank the two anonymous reviewers for the critical revision to the manuscript.

\section{REFERENCES}

Aksu, Z. (1998). Biosorption of heavy metals by microalgae in batch and continuous systems. In: Wong YS, and Tam NFY (eds) Algae for waste water treatment. Springer Germany 99:37-53.
Aksu, Z., Özer, D., Ekiz, Kutsai, T. and Çaglar, A. (1996). Investigation of biosorption of chromium (VI) on $C$. crispata in two-staged batch reactor. Environ. Technol. $17: 215-220$.

Ali, I. and Gupta,V.K (2007). Advances in Water Treatment by Adsorption Technology. Nat. Protoc. 1:2661-2667.

Arica, M.Y., Tüzün, I., Yalçin, E., Ince, Ö and Bayramoglu, G. (2005). Utilisation of native, heat and acid-treated microalgae Chlamydomonas reinhardtii preparations for biosorption of $\mathrm{Cr}(\mathrm{VI})$ ions. Process Biochem. 40:2351-2358.

Bartlett, R.J and James, D. (1979). Behavior of chromium in soils, III oxidation. J. Environ. Qual. 8:31-35.

Bertrand, M., Schoefs, B., Siffel, P., Rohacek K and Molnar, I. (2001). Cadmium inhibits epoxidation of diatoxanthin to diadinoxanthin in the xanthophyll cycle of the marine diatom Phaeodactylum tricornutum. FEBS Lett. 508:153-156.

Biggs, B.J.F. (1989). Biomonitoring of organic pollution using periphyton, South Branch, Canterbury, New Zealand. J. Mar. Freshwater Res. 23:263-274.

Dai, R., Yu, C., Liu, J., Lan, Y and Deng, B. (2010). PhotoOxidation of $\mathrm{Cr}(\mathrm{III})$-Citrate Complexes Forms Harmful Cr(VI). Environ. Sci. Technol. 44:6959-6964.

Deng L., Wang, H. and Deng, N. (2006). Photoreduction of chromium $(\mathrm{VI})$ in the presence of algae Chlorella vulgaris. J. Hazard. Mat. 138:288-292.

Dönmez, G.C., Aksu, Z., Öztürk, A. and Kutsal, A. (1999). A comparative study on heavy metal biosorption characteristics of some algae. Process Biochem. 34:885-892.

Eaton, A.D., Clesceri, L.S. and Greenberg, A.E (2000). Standard Methods for the Examination of Water and Wastewater, 17th ed., American Public Health Association, American Water Works Association, Water Pollution Control Federation, Washington, DC.

Franklin, N.M., Stauber, J.L., Markich, S.J and Lim, R.P. (2000). pH dependent toxicity of copper and uranium to tropical freshwater alga (Chlorella sp.). Aquat. Toxicol. 48:275-289.

Genter, R. B. (1996). Ecotoxicology of Inorganic Chemical Stress to Algae. In: Stevenson, R.J., Bothwell, M.L and Lowe R.L. (eds), Algal Ecology: Feshwater Benthic Ecosystems. Academic Press, San Diego, California: pp 403-468.

Gomà, J., Rimet, F., Cambra, J., Hoffmann, L. and Ector, L. (2005). Diatom Communities and Water Quality Assessment in Mountain Rivers of the Upper Segre Basin (La Cerdanya, Oriental Pyrenees). Hydrobiologia 551:209-225.

Guillard, R.R.L. and Lorenzen, C.L. (1972). Yellow green algae with chlorophylle c. Phycologia 8:10-14. 
Gupta, V.K. and Ali, I. (2002). Adsorbents for water treatment: Low cost alternatives to carbon Encyclopedia of surface and colloid science, Hubbard, A. (Ed), Marcel Dekker, New York 1: 136 pp.

Gupta, V.K., Carrott, P.J.M., Ribeiro Carrott, M.M.L., and Suhas. (2009). Low cost adsorbents: Growing approach to wastewater treatment - a review. Crit. Rev. Environ. Sci. Technol. 39:783-842.

Gupta, V.K and Rastogi, A. (2008). Biosorption of lead (II) from aqueous solutions by non-living algal biomass Oedogonium sp. and Nostoc sp. -A comparative study. Colloid. Surface. B. 64:170-178.

Gupta, V.K., Shrivastava, A.K and Jain, N. (2001). Biosorption of chromium ( $\mathrm{VI}$ ) from aqueous solutions by green algae spirogyra species. Water Res. 35:40794085.

Han, X., Wong, Y.S., Wong, M.H and Tam, N.F.Y. (2007). Biosorption and bioreduction of $\mathrm{Cr}(\mathrm{VI})$ by a microalgal isolate, Chlorella miniata. J. Hazard. Mat. 146:65-72.

Hervey, R.J. (1949). Effect of Chromium on the Growth of Unicellular Chlorophyceae and Diatoms. Bot. Gaz. 111:1-11.

Jennett, J.C., Hassett, J.M. and Smith, J.E. (1980). The use of algae to control heavy metals in the environment. Miner. Environ. 2:26-31.

Kawecka B. and Olech M. (2004). Diatom diversity of streams in Finnish Lapland and maritime Antarctica, Seventeenth International Diatom Symposium 2002. M. Poulin (ed), Ottawa, Canada, pp 161-186.

Kawecka B., Olech, M., Nowogrodzka-Zagórska, M. and Wojtuń, B. (1998). Diatom communities in small water bodies at $\mathrm{H}$. Arctowski Polish Antarctic Station (King George Island, South Shetland Islands, Antarctica). Polar Biol. 19:183-192.

Kowalski, Z.J. (1994). Treatment of chromic tannery wastes. J. Hazard. Mat. 37:137-144.

Langmuir, I. (1916). The constitution and fundamental properties of solids and liquids. J. Am. Chem. Soc. 38:2221-2295.

Levkov, Z. and Krstic, S. ( 2002). Use of algae for monitoring of heavy metals in the River Vardar, Macedonia. Mediterranean Marine Science. 3/1:99112.

Moreno-Garrido, I. (2000). Influence of cellular density on determination of EC50 in microalgal growth inhibition tests. Ecotox. Environ. Safe. 47:112-116.

Moreno-Garrido, I., Gonzalez-Delvalle, M. and Lubian, L.M. (1997). Acumulación de cobre en microalgas marinas usadas en acuicultura. Actas del VII Seminario de Química Marina, Servicio de Publicaciones de la Universidad de Cádiz: 279-286.
Morin S., Duong, T.T., Dabrin, A., Coynel A., Herlory, O., Baudrimont, M., Delmas, F., Durrieu, G., Schafer, J., Winterton, P., Blanc, G. and Coste, M. (2008). Long term survey of heavy metal pollution, biofilm contamination and diatom community structure in the Riou-Mort watershed, South West France. Environ. Pollut. 151:532-542.

Noga, T. and Olech, M.A. (2004). Diatom communities in moss creek (King George Island, South Shetland Islands, Antarctica) in two summer seasons: 1995/96 and 2001/02. Oceanol. Hydrobiol. St. 33:103-120.

Norberg-King, T.J. (1993). A Linear Interpolation Method for Sublethal Toxicity: The Inhibition Concentration (ICp) Approach (Version 2.0). National Effluent Toxicity Assessment Center Technical Report 03-93, Environmental Research Laboratory, Duluth, MN 55804.

OECD (Organization for the Economical Cooperation and Development). (1984). OECD Guideline 201 for tesing of chemicals: alga, growth inhibition test. Adopted 23 March 2006.

Patricia A. and Stone, T.W. (2002). Biosorption of cadmium and copper contaminated water by Scenedesmus abundans. Chemosphere 47:249-255.

Pena-Castro J.M. (2002). Interaccion de los metales pesados $\mathrm{Cd}$, Cu y $\mathrm{Cr}$ con la microalgae Scenedesmus incrassatulus: importancia biologica y evaluacion de sucapacidad de remocion. PhD Thesis, Departamento de Biotecnologıa y Bioingenierı, Cinvestav-IPNMéxico.

Pickering, D.C and Puia, I.L. (1969). Mechanisms for the uptake of zinc by Fontinalis antipyretica. Physiol. Plantarum 22:653-661.

Potapova, M. and Charles, F.D. (2007). Diatom metrics for monitoring eutrophication in rivers of the United States. Ecol. Indic. 7:48-70.

Sbihi, K. 2006. Rôle de la diatomée Planothidium lanceolatum (Brébisson) Lange-Bertalot dans l'autoépuration des systèmes aquatiques da la région de Marrakech (Cas de l'Ourika et de Tensift). Mémoire de fin d'étude en DESA, University Cadi Ayyad of Marrakech: 35 pp.

Scandiaconsult International, 1999. Etude de la réduction des rejets industriels sur la qualité des eaux des bassins d'Oum Er Bia et de Tensift, Maroc. Rapport du Ministère du Commerce de l'Industrie et de l'Artisanat, Division de la protection de l'Environnement : $97 \mathrm{pp}$.

Smith, R.G. and Lec, D.H.K. (1972). Chromium in Metallic Contaminants and Human Health. Academic Press, New York.

Soudi, B. and Xanthoulis, D. (2006). Elaboration des fiches techniques des valeurs Limites des Rejets industriels: Pigments et colorants. Organisation des Nations Unies pour l'Alimentation et l'Agriculture (FAO) et la Direction 
de la Recherche et de la Planification de l'Eau Maroc, Rome: 20 pp.

Stauber J.L. and Davies, C.M. (2000). Use and limitations of microbial bioassays for assessing copper bioavailability in the aquatic environment. Environ. Rev. 8:255-301.

Stomberg, A.L., Hemphill, D.D. and Volk, V.V. (1984). Yield and elemental concentration of sweet corn grown on tannery waste-amended soil. J. Environ. Qual. 13:162166.

Torres, E., Cid, A., Herrero, C. and Abalde, J. (1998). Removal of cadmium ions by the marine diatom phaeodactylum tricornutum bohlin accumulation and long-term kinetics of uptake. Bioresource Technol. 63:213-220.

Tiglyene, S., Mandi, L. and Jaouad, A. (2005). Enlèvement du chrome par infiltration verticale sur lits de Phragmites australis (Cav.) Seudel. J. Water. Sci. 18/2:177-192.

Volesky, B. (1994). Advances in biosorption of metals: selection of biomass types. FEMS Microbiol. Rev. 14:291-302.
Vymazal, J. (1990). Uptake of lead, chromium, cadmium and cobalt by Cladophora glomerata. B. Environ. Contam. Tox. 44:468-472.

Wang, W.X and Dei, R.C. (2001). Influences of phosphate and silicate on $\mathrm{Cr}(\mathrm{VI})$ and $\mathrm{Se}(\mathrm{IV})$ accumulation in marine phytoplankton. Aquat. Toxicol. 52:39-47.

Whitton, B.A and Kelly, M.G. (1995). Use of algae and other plants for monitoring rivers. Aust. J. Ecol. 20:4556.

Wilde, E.W. and Benemann, J.R. (1993). Bioremoval of heavy metals by the use of microalgae. Biotechnol. Adv. 11:781-812.

Yang, L. and Chena, J.P. (2008). Biosorption of hexavalent chromium onto raw and chemically modified Sargassum sp. Bioresource Technol. 99:297-307.

Zerhouni, R. A. (2003). Flore algale des eaux usées de la ville de Fès et étude de la capacité de certaines espèces à éliminer la charge azotée, phosphatée et quelques métaux lourds (Chrome et Cadmium), PhD Thesis, University Sidi Mohamed Ben Abdellah of Fès: $146 \mathrm{pp}$. 